Est Ag 52 (2017) 577-598

\title{
Religious conflicts in pluralist societies
}

\author{
Peter G. PANDimakiL
}

RESUMEN: Los conflictos religiosos en la India contemporánea a menudo se retratan como expresiones del nacionalismo hindú, fundamentalismo o comunalismo. Aunque estas caracterizaciones son en su mayoría correctas, no ofrecen un marco general para comprender y resolver esos conflictos, que surgen también debido a las desigualdades económicas y sociales. Además, los conflictos religiosos a menudo desafían la base ideológica fuerte sobre la cual se funda el Estado-nación. Es la legitimidad de los fundamentos de la democracia india que están directa o indirectamente en peligro en los conflictos religiosos, a menudo también desatados por las políticas de derecha radical. Este ensayo intenta manifestar esta tendencia actual, llamando la atención sobre las leyes de protección animal y la supuesta justificación de que en la tradición hindú. De este modo, se destaca el criterio sólido -ahimsa e inclusión social- para juzgar los conflictos religiosos, y el papel que desempeña la religión en su salvaguardia.

Palabras Clave: Valores del Índico; ahimsa, exclusión social; soberanía ética; Hindutva.

ABSTRACT: Religious conflicts in contemporary India are often portrayed as expressions of Hindu nationalism, fundamentalism or communalism. Though these characterisations are mostly right, they do not offer an overall framework to comprehend and resolve such conflicts, which emerge also due to economic and social inequalities. Further, religious conflicts often challenge the strong ideological basis on which the nation-state is founded. It is the legitimacy of the foundations of the Indian democracy which are directly or indirectly in jeopardy in religious conflicts, often also unleashed by radical right-wing policies. This essay attempts to manifest this current trend, by calling attention to the animal protection laws and the purported

${ }^{1}$ Excerpt from a forthcoming book: Fatherland, Motherland, Holy land: Religious Conflicts in Post-Independence India. 
justification of which in the Hindu tradition. It thereby highlights the sound criteria -ahimsa and social inclusion- to judge religious conflicts, and the role religion plays in safeguarding them.

KEY WORDS: Indic values; ahimsa; social exclusion; ethical sovereignty; Hindutva.

On 26th February 2015, after some nineteen years of its approval by the State Government of Maharashtra, the president of India, Pranab Mukherjee, has signed into law the amendment prohibiting calf slaughter $^{2}$. The signing of the amended bill was reported in the media, and they all highlighted the fact that the Bharatiya Janata Party (BJP) and the Shiv Sena factions, while together in power in the state, passed the amendment in 1995; and it had the explicit intention of broadening the bill banning cow slaughter approved in 1976 under the then Congress-led State Government.

Two points deserve special mention: first, the Maharashtra Animal Preservation Bill has been proposed and supported by the Indian National Congress (INC) as well as by the BJP; in a certain sense, it does not hence reflect partisan politics, but responds to an issue of high sensitivity to Hinduism, the religion of the majority. Second, this recognition of a major trait of Hinduism, namely vegetarianism, as a national value slips easily into the hands of contemporary Hindu nationalists, the propagators of Hindutva. Within this category of national values advocated by the nationalists (and others) shall be included the absolute ban on alcohol consumption in some Indian states (Gujarat, Kerala ${ }^{3}$, Manipur, Mizoram, and Nagaland) and in the union territory of Lakshadweep. The ban is also supported by the major minority religion in India, namely Islam. But in this regard, all the major seven religions of India - Hinduism, Islam, Christianity, Sikhism, Buddhism, Jainism and Zoroastrianism - concord;

$2 \mathrm{http} / / /$ www.sanskritimagazine.com/newsworthy/cow-calf-slaughter-banned-inmaharashtra/; http://www.thehindu.com/news/cities/mumbai/calf-slaughter-banned-in-

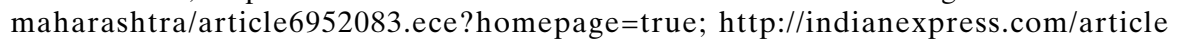
/india/india-others/beef-banned-in-maharashtra-5-yrs-jail-rs10000-fine-for-possession-orsale/; Miller, Michael E., "A mob in India just dragged a man from his home and beat him to death - for eating beef", en Washingtonpost.com (30 Sept. 2015); KHAN, Taran N. McClatchy, "Mumbai's beef ban. A swipe at cultural diversity", en Tribune Business News [Washington], 20 Mar. 2015.

3 This recent bill, passed by the State Parliament on $22^{\text {nd }}$ august, 2014, proposes a phased, total prohibition in 10 years; see: http://www.bbc.com/news/world-asia-india28892073. 
and the issue is not exclusively about a simple ban on drinking, despite the severity of the matter from a public health perspective. It has multiple connotations capable of inciting discrimination and violence. The apparently innocent and presumably well-intentioned animal protection law has thus deeper religious, social, cultural and political implications.

This essay discusses the contemporary Indian scenario of religious conflicts by analyzing three interrelated dimensions: historical, theoretical and socio-political. The analysis should elucidate the complexity implicit in and the brutal violence incited, if not perpetrated, by religious conflicts. The first part sets the stage, briefly describes the broader realm of values in which religious violence makes (non)sense and concerns the recent approval of the animal protection law by the President of India (I). The second part consists of conceptual clarifications of three sorts: first, all religious conflict is set within the current Indian context of a liberal, federal, secular, pluralist democracy. This is necessary for a better grasp of the entrenched conflicts with multiple dimensions, rationalized under divergent if not contrary perspectives. In the Indian context, there is a strong emphasis on understanding and interpreting religious conflicts as an intrinsic part of the political conception of the nation. Second, conflicts involving religion can however also be dealt with a primary emphasis on social order, and the political interest in such cases would be to highlight the issue of security. It is often done by questioning or denying the legitimacy of religion in the society; this shall be denoted as religion conflict, as evidenced by Maoist China, Stalinist Russia, and the Marxist Communist India, for example. Third, within and alongside this paradigm should be set the longstanding issue of caste, recast in a unique way by Bhimrao Ambedkar, one of the architects of the Indian Constitution (II).

The third and fourth parts, not included in this essay, discus some of the most well-known recent, violent conflicts. In raising them, it is not intended to offer a full or detailed conflict analysis, but to highlight a pattern typical of India, which may also resemble the structural violence initiated and perpetuated by religious ideologies and practices elsewhere. The case of Hindutva would be very pertinent in this analysis.

Hindutva's alternative claim is analyzed in the fourth part. It considers the various modes in which Hindutva makes the claim of sovereignty, thereby denouncing democratic values, undermining freedoms and minority rights, and institutionalizing a specific form of ethical sovereignty which ultimately thrives on violence. The analysis thus brings the reader back to the recent legislation on cow slaughter, its ethical relevance, 
ambiguous legitimacy, potential for violence and clear affront of individual democratic rights.

This last part shows the dangers of narrow religious fundamentalism which may take different forms in the public sphere. The case of India becomes hence a paradigm not only to comprehend the Islamic State's ideology, but also to guard against the threats contemporary pluralist democracies are poised at. Overall the study presents a concise and contextual analysis of the scenario of religious conflicts in India after the independence and the formation of the federal democratic secular state. A brief sketch of Indic/Hindu values that underpin the nation-state is hence a good starting point.

\section{IMPORT Of Historical InSIGHTS}

\section{Renouncers, householders and social order}

Ahimsā (non-harming others) is central to Hinduism, but also, perhaps more, to the other Indic religions such as Buddhism and Jainism. Concentrating for the time being on the formative period of Hinduism (600 BCE - $400 \mathrm{CE}$ ), the issue of violence shall be dealt with from various interrelated perspectives, namely religious/moral, ethical and social. A first set of insights is offered from the textual traditions with respect to renunciation and domesticity, the texts in question being some Vedic writings including the Upani ads; and a second set of insights shall be drawn from the writings categorized as sūtras ("threads": truth claims), śāstras (ancient and authoritative treatises) and purānas (primordial narratives), wherein violence is formalized in religious, political and legal terms. The two Indic epics, Rāmāyaṇa and Mahäbhärata $(M B)$ dating back to $300 \mathrm{BCE}-200 \mathrm{CE}$, both critique and affirm the perspectives of the earlier periods, thus enabling transformations but maintaining the continuity of Hindu thought. The different stages of thought, corresponding to the formation of religious ideas mentioned here, do not set apart sharply from each other; they rather flow into one another or coexist. Consequently, patterns of violence critiqued at one period may not be excluded in the subsequent stage, but may take a different shape. In other words, the dimensions of violence mentioned above, namely religious, moral, political and social, coexist in all periods, a particular dimension having the preponderance at one stage over the other.

Whereas the Vedic religion placed great emphasis on sacrifices, and Brahmins were the sole legitimate persons to conduct them, critique of 
sacrifice involving animal victims was raised, by the ascetic (śramana) traditions ${ }^{4}$ which placed the renouncer's life-style above that of the householder, opting clearly for the path of flame over that of smoke or of tiny creatures. For, whereas the latter meant incessant cycles of re-births, the former two promised/ensured the attainment of purușārthas (aims of life): wealth (artha), righteousness (dharma), pleasure ( $k a \bar{m} m a)$ and liberation (mokșa) and freedom from this-worldly entanglements (saṃsāra). In this understanding, control of oneself, the self-transcendence thanks to the knowledge of the self, is not only equal to but also surpasses all sacrifice. This predominantly upanișadic critique of the sacrifice carried over by the subsequent epic and purānic texts must have put an irrevocable end to all animal sacrifices highly exalted in the Vedic literature; sacrifice is henceforth substituted by offerings of fruits, vegetables, etc. 5 .

However, the origins of Indic religions are marked by renouncer as well as householder traditions, the history of which, though not completely indisputable, amounts both to an ideological hitherto unresolved conflict between ways of life and also between social groups. In the former case, one can talk of at least "two competing ascetic traditions ...: anchorites living settled lives in forest hermitages cut off from social intercourse, and renouncers living itinerant lives in the wilderness but in interaction with towns and villages from which they begged their food"6. Both these groups contrast with the Brahmins for their refusal to practice sacrificial rituals, though the anchorites kindled the sacred fire alike the Brahmins. But fire ${ }^{7}$ defined the Brahmin householder "in the role of the śrauta sacrificer". This has been the "ideal and typical religious life within the Vedic ideology"9 which was challenged by the renouncer tradition.

The challenge consisted not only in proposing new ways of obtaining liberation from the samsāra (the world of suffering and rebirth) as pro-

${ }^{4}$ Flood, Gavin, An Introduction to Hinduism, Cambridge Uni. Press, Cambridge 1996, 81-82.

5 Doniger, Wendy, The Hindus. An Alternative History, The Penguin Press, New York 2009, 164-193.

6 Olivelle, Patrick, "The Renouncer Tradition", en Flood, Gavin (ed.), The Blackwell Companion to Hinduism. Blackwell Publishing, Oxford, UK 2005, 271.

7 The "solemn, public" (śrauta) rites contrasted with the "domestic, life-cycle" ( grhya) rites "by the number of fires used. The śrauta rites required the burning of three sacred fires, while the domestic observances required only one". Flood, Gavin, An Introduction, 41 .

8 Madan, T. N., "The Householder Tradition in Hindu Society," en: Flood, The Blackwell Companion, 291.

9 Olivelle, Patrick, The āśrama System. The History and Hermeneutics of a Religious Institution, Oxford University Press, New York 1993, 36. 
posed by Buddhism, Jainism and by the sect of renouncers rejecting free will (Äjivikas) or by denouncing the "doctrine of debts" but also by conceptualizing the stages of life (āśramas) as an alternative way of life: “... the original system gives equal weight to all āśramas and, ...gives the candidates total freedom of choice among the competing modes of life. Permitting choice, indeed, placed renunciation and celibacy on an equal footing with household life" 10 . Howsoever freedom oriented this "urban invention" were, the renouncer tradition had to face the formidable challenge of the Brahmin householder/sacrificer who found the individualistic/voluntarist life-choice threatening both on religious and social levels. The Brahmin response to the renouncer traditions consisted in two crucial socio-religious transformations, namely the integration of àśramas within the householder tradition and the formalization of dharma according to the varnas, hence, varnāśramadharma, "that is, dharma appropriate to each stage of life and, concomitantly, each varna" 11 . Consequently, there emerges the classical pattern of Hindu life consisting of the four stages of life (āśramas), and the personal obligations of the twice-born defined by one's belonging to one of these groups. It is this formulation of the householder who treads "the middle ground, combining the values of domesticity and detachment" that is upheld ${ }^{12}$. Despite critique from co-religionists, this perspective constitutes the Hindu ideology in contemporary India ${ }^{13}$. And the textual tradition often called for its legitimacy is that of the authoritative and paradigmatic text the Dharmaśāstra of Manu (MDh).

Composed most probably in the second century CE, its sociopolitical context indicates a rupture of political-religious power relationship between the Brahmins and the Aśokan regime ${ }^{14}$. By banning animal sacrifice, the Aśokan regime recognized two equally powerful social groups, the Brahmins and the ascetic (śramana) communities; it thus denied/debilitated the exclusive privilege of the former both in sacrifice and knowledge. Further, the Brahmins considered that the usurpation of power by the serf-class (Śúdras) would lead to mixture of classes (varnasarkara), a sign of decadence marking the epoch of Evil (kali

10 Olivelle, "The Renouncer Tradition”, 275.278.

11 MADAN, "The Householder", 293.

12 Ibid., 302.

13 Olivelle, "The Renouncer Tradition", 285.

14 Thapar, Romila, “Aśoka. A Retrospective", en Olivelle, Patrick - Leoshko, Janice - RAY, Himanshu Prabha (eds.), Reimagining Aśoka. Memory and History, Oxford University Press, New Delhi 2012, 18s. 
$y u g a)$. A rivalry between Buddhism and Brahmanism emerged during this period thanks to the foreign, central Asian invader, Kușāna regime which favored Buddhism. In resolving this sociopolitical crisis, the $M D h$ establishes the varnāśramadharma as the social order, promotes hierarchy reinstating the Brahmin's "unique and privileged position within society", which would be safeguarded by the king and the laws ${ }^{15}$. Violence is, so to say, centralized under the royal power and brought under legal jurisdiction. With the $M D h$, dharma is more and more understood as law, including the local custom ( $\bar{a} c \bar{a} r a)$ : "The dharma taught in the dharmaśastras has little to do with the Veda but reflects the actual practices of local groups" 16 . This jurisprudence shall hence be challenged, or ignored by other texts of the same genre.

Thus the $M D h$ presents an imaginative-constructivist structure of a society deriving the caste from the Vedic conception of class (varna), a social taxonomy uniting lineage-linked species ( $j a \bar{t} t i)$ with class, legitimizing the social structure by homology and hierarchy, and extolling the status of the Brahmins. Though the Arthaśastra $(A S)$ accepts this taxonomy, it does not dwell much on the caste/class system, but on groups distinguished by religion or profession. In contrast to both $M D h$ and $A S$, Kãmasūtra ignores caste ${ }^{17}$; it concentrates on the moneyed man of the city (nāgarika) endorsing so to say an American model of 'capital-driven' social system. The caste/class system conceptualized by Manu considers the lower castes as functionally useful, socially separate and religiously polluted. In other words: "They are economically exploited, victims of social discrimination, and permanently polluted ritually" 18 . However, there is an aspect common to all these three texts: the emphasis on controlling addiction, and warning one of the four vices of lust: "gambling, drinking, fornicating and hunting" 19 . In this sense, they all aim at promoting the purușārthas within a well-ordered but pluralist society, despite their differing ranking of life's ends. The challenges involved in such a

15 Olivelle, Patrick. "Dharmaśāstra: a textual history", en Lubin, Timothy DAvis, Donald R. Jr. - KrishnAn, Jayanth K. (eds.), Hinduism and Law: An Introduction, Cambridge University Press, Cambridge, UK 2010, 43.

16 Ibid., 34; cf. Olivelle, Patrick, Ascetics and Brahmins. Studies in Ideologies and Institutions, Anthem Press, New York 2011, 271-291.

17 DONIGER, Wendy - KAKAR, Sudhir, "Introduction", en Vatsyayana. Kamasutra (translated and edited by Wendy Doniger - Sudhir Kakar), Oxford University Press, Oxford, UK 2003, xxvii.

18 DONIGER, The Hindus, 313.

19 Ibid., 320. 
conception become a salient topic of the epic $M B$, besides violence and addiction.

\section{Animal Protection: sensitivity and benevolence}

The epic Mahābhārata, alike the sūtras, śāstras and purānas, falls within a category of Hindu religious literature commonly referred to as smṛti ('what is remembered') texts in contrast to the Vedas, Brāhmaṇas and Upanișads generally known as śruti ('what is heard') texts. Their difference (for our purposes) consists in the kind of authority attributed to them: whereas the former category possesses a derived or relative authority, the latter is reckoned as absolute thanks to their impersonal (apaurussya) feature ${ }^{20}$. For it consists of wisdom or knowledge received, or listened to (hence śruti) from beyond; it is a moral source not selfmade, or reflected upon nor argued about. Hence the legitimacy of śruti literature does not have to be warranted by human assent or consent. The authority is given; it rests upon factors beyond (but not excluding) the human sphere; it is, in this specific sense, eternal (sanātana): foundational and unchallengeable. Or, as contemporary communitarianism would argue, the texts of this category refer to a domain of obligations one has to submit to, although these are not born of communitarian consensus, but determine the very existence of communities ${ }^{21}$.

This quasi-transcendental legitimacy attributed to the śruti literature is carried over to post-Vedic Hinduism thanks to two central conceptions, rta and dharma, both of which constitute the basis of correct action in every day Hindu life. Although rta stood for 'the Lord of righteousness' in the Vedic period, later thought considered rta as 'the sacred order or law ... of the universe'22. Here is an example of the homology typical of Hindu thought, in this case a correlation between the cosmic and the social orders. It appears in the Vedic period together with a hierarchy, classifying the society into four groups (varnas) corresponding to the sacrificial body of the Cosmic Person, Purușa (RV 10.90). Further reflection

20 The term authority refers in this context to religious/moral/social legitimacy attached to beliefs and practices, which may serve as the foundation for political authority (Brück, Michael von, "Political Authority. A Christian Perspective", en Buddhist-Christian Studies 30 [2010] 159-170); it goes beyond the strict sense of textual canonicity in Western/Christian thought (LuBIN, Hinduism and Law). 15-19.

21 FABre, Cécille, Justice in a Changing World, Polity Press, Cambridge, UK 2007,

\footnotetext{
22 FLOOD, An Introduction to Hinduism, 45.49.
} 
on this model as well as repercussions of this pattern of thought are to be found in the smrti literature, including the $M B$, and the classical philosophy. The famous dialogue between Krșna and Arjuna (the entire Bhagavadgittā, $B G$ ) centers around the varnasśramadharma, the social and personal obligations arising from one's belonging to a fixed group defined by consanguinity, social function and hierarchy. However, the smrti texts, in contrast to the śruti literature, approach these issues within the realm of derived authority. They are context-bound; their sense is anchored on concrete events experienced, related and remembered. One is hence in a domain of rules, norms and laws to be discussed, reflected, argued about and consented to. Though not exclusively or for the major part individualistic, they tend towards a conception of the individual resembling the contemporary notion of voluntarist personal obligation. Still the moral source exerts a significant hold on later ethical conceptions.

The ethical considerations regarding violence are centered on social and personal obligations of a member defined within the group (varnāśramadharma), as mentioned above. Both homology and hierarchy come to play here thanks especially to the use of animal metaphors. Doniger's ${ }^{23}$ analysis of violence in the $M B$ unveils this strategy of subliminal social critique and the dithering acceptance of the caste system. The gist of her analysis, for our current purpose, shall be presented concisely as follows: first, however "rotten the caste system is" (269), $M B$ alike other smrti texts does not condemn it; the derived authority of these texts consists in presenting possible consequences of discriminatory violence, by resorting to the homology referred to above.

Thus a dog symbolically representing the upwardly mobile lower cast shall be seen as a threat to the hierarchical social order, but at the same time it presents the image of a dedicated passionate devotee (though fully developed only in later Hinduism) alike the canine companion of Yudhisthira, the steadfast adherer of dharma in the $M B$; "the Mahabharata both begins and ends with a story about justice for dogs"24. Whereas the epic narrative argues convincingly for the equality of persons irrespective of caste considerations, and thus both the twice-born Yudhișthira and his faithful 'stray dog' (representing the lowest caste) may enter the paradise, in fact the realized just situation is not depicted in the text; it remains still a (thoroughly justified) possibility. For, the whole incident is portrayed as a test of Yudhisthira's righteousness, not as

\footnotetext{
23 Doniger, The Hindus, 252-276.

24 Ibid., 269.
} 
a precursor of realized justice for the down-trodden castes in the future. Second, though violence against animals cannot be defended by violence of animals, killing of animals cannot also be abolished totally. "Extending ahimsa into a universal law ... beyond the human world ... would make most creatures starve to death" (273). Hence from an ethical perspective ahimsā sets a priority or a gradation without resolving the issue of killing animals for food or killing one's enemies in the battlefield.

The $B G$ highlights the latter issue, but dwells on it with theological, metaphysical and psychological arguments, which gave Sen ${ }^{25}$ the occasion to propose his own innovative perspective of 'comprehensive consequentialism' as the option advanced by Arjuna. This pluralist paradoxical outcome shall be succinctly expressed by the terms the Indic texts hitherto employed to talk of ahimsaa: adrōha (nonhostility to all creatures), anțișamsa (nonhostility/noncruelty to all humans) and anukroșa (weeping with or compassion towards all creatures) ${ }^{26}$. Thus the classical Hinduism, including also its Purānic insights, offers a broad, pluralist, multicontextual understanding of violence ${ }^{27}$, and proposes ahims $\bar{a}$ as the ideal pattern of interaction between humans and animals, humans and humans, as well as humans and gods. This multi-faceted basis of ahimsā should not be ignored in considering the further elucidations and legal-political applications of it, to which we shall return below on various occasions.

\section{Import of Political Insights}

Whereas the above discussion indicates the complexity and the changed reality of lived religiosity in classical Hinduism, ${ }^{28}$ it also highlights the central values shared by all Indic religions (namely Hinduism, Buddhism, and Jainism): ahimsā in its different connotations shall be considered as the highest among all these values in political and religious thought. The relevance of this Indic tradition emerges, if modern Indian political thought is read through categories such as 'swaraj, the self's

25 SEN, Amartya, The Idea of Justice, Harvard University Press, Cambridge, MA 2009, 208-221.

26 DONIGER, The Hindus, 270-275.

27 Patton, Laurie L., "Telling stories about harm. An overview of early Indian narratives", en Hinnells, John R. - KING, Richard (eds.), Religion and Violence in South Asia. Theory and Practice, Routledge, London - New York 2007, 33.

28 On the problematics of using the term 'Hinduism' and its contemporary ir/relevance, see: KING, Richard, "Orientalism and the Modern Myth of 'Hinduism”, en Numen 46 (1999)146-185. 
sovereignty, ahimsā, the self's orientation, viraha, the self's longing, samvega, the self's shock, dharma, the self's aspiration, artha, the self's purpose and duhkha, the self's burden'29. This insight serves as a feature of the following discussion on the democratic foundations of contemporary India, religious conflicts and caste-based violence.

\section{Liberal, federal, secular, democratic republic}

Though modeled after the British democratic system, the Indian democracy is liberal, federal and secular in some specific senses ${ }^{30}$. It is liberal in ideology, that is, places emphasis on individual autonomy, but at the same time defends communitarian rights. Whereas individual rights are reflected in the electoral system, communitarian authority is preserved in the personal laws, for example in the Muslim marriage and inheritance code. This curious mixture, among other factors, has led scholars to consider the Indian society as traditional. However, the individual-communitarian conception of society adhered to by the Indian Constitution affirms multiple kinds of diverse groups constituting the nation. It is the religious, ethnic, linguistic, and caste diversities which this mixed conception of society underlines. Indian liberalism views hence the individual as embedded in the group; what counts first and foremost is the in-group identity which served as the basis for the national sense of unity during the independence struggle. The formative period of Indian democracy reaffirms this inclusive identity in terms of liberal nationalism, evoking civil liberties, equality and social justice, including the "right to actively resist illegitimate state power" 31 .

Wanting to hinder hierarchical communitarianism, Indian constitution wavered between "individualist" and "communitarian egalitarianism" 32 which led to "the majority-minority framework". The key point here is the attitude towards the differences, and the understanding of their sources. Whereas the individualist perspective viewed "difference as disadvantage", the communitarian did acknowledge the differences without wanting to eliminate them. By incorporating group rights, the Indian

${ }^{29}$ VAJPeYi, Ananya. Righteous Republic. The Political Foundation of Modern India, Harvard University Press, Cambridge, MA 2012, xxii-xxiii, 1s.

30 Bhargava, Rajeev, The Promise of India's Secular Democracy, Oxford University Press, New Delhi 2010, 3-105.

31 Ibid., 8.

32 Ibid., $15 \mathrm{~s}$. 
constitution accepted the majority-minority framework, enabling e.g. the minority educational institutions. This helped also to redress "the majority-minority syndrome" 33 : alienation and/or insecurity of minorities within a democratic system, especially due to hidden inequalities and possible injustices. However, majorities shall be conceived as: "preference-based" (electoral choices or eating preferences, for example) or "identity-dependent" (with recognizable attributes, the Sikhs in Punjab for example) ${ }^{34}$. The Indian liberalism wants to safeguard both, and thereby becomes a possible source of conflict.

The federalism ${ }^{35}$ embraced by India is characteristically linguistic; it is a late addition (since 1956), ongoing and with political overtones. Its modern colonial origin betrays a tension between a unitary and federal state. Under the British, there existed devolution of power to the provincial authority (in 1919 \& 1935); this did not mean provincial autonomy, but power was centralized: all important decisions were made at the center, the provincial administration, deprived of participation in the decision-making, had to carry them out. After the partition of the British Raj in 1947 on religious grounds and the ensuing violence, ethno-linguistic federalism also did come under suspicion ${ }^{36}$. For it was argued that it would give unfair advantage to some politicians, freeze communal identities, hinder collective identity and lead to possible fragmentation of the country. Further, bias towards the center was constitutionalized in terms of uniform criminal law, single citizenship, single judiciary, unified civil service; and no state was to have a right of secession from the union. Hence, the Achilles' heel of Indian federalism seems to be the "Centerperiphery" imagery which serves as yet another source of conflict unless remedied with "a strong Union" 37.

The second salient feature of Indian liberal democracy is secularism. Indian secularism is distinct thanks to the following three features: principled distance from religion; community-specific rights and contextual sensitivity. However, it should not be seen as a perpetually fixed notion: its ambiguity is a virtue inviting new interpretation. Its basis is both western and Indic; and suits better for pluralist societies. The Indian Constitu-

\footnotetext{
33 Ibid., 19s.

34 Ibid., 15s. 152s.

35 Ibid., 34-62.

36 GuHA, Ramachandra, India after Gandhi. The History of the World's Largest Democracy, Harper Collins, New York 2007, 128s.393s.

37 Bose, Sumantra, Transforming India. Challenges to the World's Largest Democracy, Harvard University Press, Cambridge, MA. 2013, 20-22.
} 
tion defends secularism as differentiated citizenship and as religious neutrality sui generis, based on socio-cultural reasons. It recognizes that multiple irreducible diversities may generate conflict over values, and hence places emphasis on pragmatic religious content. This entails the introduction of strategies to reform religious practices which may be socially oppressive, and/or lack organized central institutions.

A similar but more nuanced defense and interpretation of Indian secularism, proposed by Bilgrami ${ }^{38}$, argues "that all religions should have the privilege of free exercise and be evenhandedly treated except when a religion's practices are inconsistent with the ideals that a polity seeks to achieve ... in which case there is a lexical ordering in which the political ideals are placed first" (12). Central to Bilgrami's understanding of secularism is that it should not be equated exclusively with state neutrality towards religions, nor with an attempt to redress the minority-majority syndrome (as mentioned above), though both these may result from secularism as defined above. The definition acknowledges a consensual commitment to pluralism and priority of values solely on the basis of internal reasons argued within historical contexts. Consequently, the implementation of secularism would be "non-coercive" or better "non-dominating" (52) -an aspect also proceeding from federalism enshrining the values of "Inter-group equality and self-governance" $39-$, which does leave space for preferential treatments like the minority rights in the Indian constitution. They are to be understood "as a temporary measure" to elicit confidence and to enable the secular commitment thanks to internal reasons ${ }^{40}$. Seen from this perspective, secularism is itself $a$ value, as well as "an evaluative stance" (44) vis-à-vis religion; it is "non-religious, rather than antireligious. ... A secular perspective is not committed to the exclusion of religion from every sphere of life or even every important sphere of it" ${ }^{41}$; it does not content with toleration, but calls for engagement with religion.

\section{Secular and Gandhian insights}

Linguistic federalism and principled secularism were highlighted above mainly for two reasons. First, both federalism and secularism are

\footnotetext{
38 Bilgrami, Akeel, Secularism, Identity, and Enchantment. Harvard University Press, Cambridge, MA. 2014, 12.

39 Bhargava, The Promise 61.

40 Bilgrami, Secularism, 54.

41 BéteIlle, André, "Secularism and Intellectuals", en Economic and Political Weekly 29.10 (1994) 566.
} 
strategies to safeguard and foment a sense of unity in the new nationstate. Second, this sense of identity is substantiated thanks to a re-imagined/re-interpreted tradition of the nation. It is this latter foundational conception of the republic which might offer a differentiated theoretical stance on religious conflicts. We shall approach it from two angles: in following up with Bilgrami's view of secularism, and in engaging constructively with the Indic categories mentioned above.

Bilgrami ${ }^{42}$ argues that secularism in the sense explained above, did not at all form part of the Gandhian conception of an independent India, because for Gandhi "to impose" it would be "a form of cognitive slavery". Gandhi saw correctly that European secularism was anti-religious; the circumstances in which it arose there did not at all correspond with the Indian scenario. Bilgrami (58s.) hence argues that from a legal perspective, the secularism he defends opts for a decision-theoretical rather than a principled conception of law (as explained below). However, Gandhi's concept of religion is more complex and nuanced, and his stance to Indian Independence adds a unique colouring to secularism.

A central feature of Gandhi's conception of religion is concisely expressed in the following statement:

Quite selfishly, as I wish to live in peace in the midst of a bellowing storm howling round me, I have been experimenting with myself and my friends by introducing religion into politics. Let me explain what I mean by religion. It is not the Hindu religion, which I certainly prize above all other religions, but the religion which transcends Hinduism, which changes one's very nature, which binds one indissolubly to the truth within and which ever purifies. Young India, 12 May 1920 (my italics).

Gandhi does not negate the current existing religions of India; there is no anti-religious stance in transcending the religions. Nor does he advocate a multi-religious stance, affirming all religions as contemporary pluralists do, where religions correspond to the 'family resemblance concept' à la Wittgenstein. The Gandhian stance corresponds to the distinction Bilgrami ${ }^{43}$ introduces between the different conceptions of law. The contrast between decision-theoretical and principle-based conception of law consists in the context sensitivity recognized and built into the very conception of law itself, so that different applications of it do not constitute exceptions or ad hoc judgements. In a similar way, the transcending of

\footnotetext{
42 Bilgrami, Secularism, 27.

43 Ibid., 64s.
} 
'religion' constitutes an essential ingredient of religion itself, as Gandhi understands and advocates it.

Gandhi's political stance is a faith perspective ${ }^{44}$, result of a personal journey, told in The Story of My Experiments with Truth, what makes it simultaneously both admirable as well as challenging for a nation. Distancing oneself critically from one's own religion becomes a sine qua non in this act of religious transcendence. Further, such a stance to religion, his "ethical religiosity" 45 , has the secular colouring thanks to which Gandhi would be ironically an "anti-secularist". For, all what official secular praxis aims to achieve is realizable with this transcending of religion. And this 'transcended' religion would take the place of secularism.

Gandhi's transcending of religion shall be substantiated by traditional Hindu values as well as by their pragmatic relevance. In the former case, we are referring to an evaluative stance to one's own religion, and in the latter case we are reminded of Gandhi's grasp of non-violent action. Gandhi embraces and re-interprets the traditional notion of ahims $\bar{a}$-often translated inadequately as non-violence- politically for the sake of swaraj (self-rule). Hence, one would argue that these two categories, despite their holistic nature in the Gandhian thought, "permit Gandhian nationalism to ground itself in the idea of a political tradition that has, at once, historical continuity, pan-Indian resonance, and a creative capacity, responsive to the needs of a rapidly transforming present"46. Significant to this Gandhian 'ethical politics' is its "insistent marriage of questions of being with questions of power that is at the heart of the Indic construction of the political" (53). In other words, Gandhi not only recognized the crisis of nationalist politics, but also, alike Galileo in the field of Western Science, proposed "an epistemological break" (55) with this nationalist, communalist, pattern of thought. What this break demanded was a reconceptualization of swaraj beyond mere political freedom, and the inclusion of the transcendental, roots of which are to be found in the $B G(60)$.

The $B G$ 's take on ahimsa prioritized the ethical dimension over the strictly religious (ritual/sacrificial) conceptions. Gandhi follows this tradi-

44 GANDHI, Mohandas Karamchand, An Autobiography Or The Story of My Experiments with Truth, Navajivan Trust, Ahmedabad 1927 505-507.

${ }^{45}$ Lannoy, Richard, The Speaking Tree. A Study of Indian Culture and Society, Oxford University Press, Oxford 1971, 389.

46 VAJPEYI, Righteous Republic, 51.

47 "... Gandhi can be seen as moving beyond a neo Vedānist ontology to a virtue ethics based on truth, nonviolence, and compassion." GIER, Nicholas F., "Gandhi, deep religious pluralism, and Multiculturalism”, en Philosophy East \& West 64 (2014) 334. 
tion, but adds the dimension of virtues/values ${ }^{47}$ within a life according to ahims ā; ahimsā becomes in the Gandhian thought, "the norm of norms (ahimsā paramo dharmah)"; and "the very ground of normativity itself (dharmo rakșati rakșitah) that allows for the upholding (dh-) of normal life" 48 . And this normal life is represented by the historical figure of Asoka (304-232 BCE) and the epical hero Yudhișthira, each in his own turn had to re-learn the radical significance of ahimsā by taking a moral stand against tyranny and murderous inclinations respectively. Gandhi's recalling of these characters creates "a political tradition ... which attempted to remove harm and the desire to harm (himsā) altogether from the equation between any two persons, ... in contrast to the western tradition ... where the social contract is premised on the capacity for mutual harm held in check traded for interests" (64, my italics). Further, the Gandhian ahimsā combines three different strands of the term evoking three types of action: 'renunciation (sannyāsa)', 'service ( $\operatorname{sev} \bar{a})$ ' and 'normative conduct in political life (dharma/dhamma)' (65). "Gandhi's brilliance ... lies in his ability to harness all three potential significations of ahimsa at once, to use it so suggest the possibility of renunciative freedom, promote the ethic of social service, and hold up the ideal of a righteous republic" (65-66). All the three refer back to non-violence which is both political and individual. Renunciation and service hold so to say the sovereign rule ( $r a \overline{a j y} a)$ within limits.

Besides individuating the sources of the Gandhian ethical politics, it shall be further argued: ahimsā implies 'a violent struggle' with oneself, corresponds to 'the relationship between the self and the other,' does not exist independently of other values/virtues such as fearlessness, compassion, truthfulness, forgiveness, etc., and above all enables one to have a hold of oneself. It is in this specific sense that Gandhian ethical politics is religious; it is a faith perspective (where truth is God), whence it holds on to truth (satyagraha) so that one has a hold of oneself. However, unlike other independent leaders or contemporary Indian intellectuals who read and interpreted the $B G$ with an emphasis on exegesis, literary criticism or political thought, Gandhi reads the text as "a guide to life" 49 . In this perspective, what counts for Gandhi is the training of the mind to face "the space wherein dharma unfolds as a conflict between options, a perpetual drama of what to do and not to do, opposing forces, like enemy armies, bearing down on the individual in a battle called life" (77). Consequently, the Gandhian adoption of ahimsā based on $B G$ proposes a radical antipolitics

\footnotetext{
48 VAJPeyi, Righteous Republic, 62.

49 Ibid., 73.
} 
wherein swaraj, self-rule, "is freedom from fear (abhaya), the achievement of true non-violence (ahimsa), and the adherence to truth (satyagraha)" (79). Further, the Gandhian conception may also be seen as incorporating the value of ānrśamsya (non-cruelty) into the self's sovereignty in the political and social realms. His preference for "a strong and virtuous Indic self" in contrast to "an ethical sovereign (dharmaśila rājā) like Yudhișthira" (83) is worth noting. "The protagonist of ahimsa and swaraj, for Gandhi, was to be a genuine satyāgrahī, not an Indian ruler who might replace the British crown."

What does all this mean in conceptualizing the contemporary religious conflicts in India? First, the Gandhian insight or innovation in ethical politics provides the nation with a refined or re-interpreted modern moral order alike the one that Charles Taylor ${ }^{50}$ assigns to the West. Ahimsā with its related values/virtues constitutes for the Indian citizenry the criteria in light of which to judge liberal, democratic, secular, and federal politics within and between the center and the states. Second, the Gandhian normative criteria pose a formidable challenge to any exclusivist interpretation or acceptance of religion in politics. That is to say, ahimnsā as a national characteristic of Indian polity would not correspond to any narrow Hindutva claims and the unity of the nation may demand a self-renouncing and religion transcending political vision. If and when the Indian polity refuses to adhere to any of these two criteria, the probability of religious conflicts increases, for it thwarts the specifically Indian framework of modern moral order. A litmus test of this case shall be exemplified by dwelling briefly on the caste issue, which was Bhimrao Ambedkar's main concern. His own conceptualization of religion and stance to tradition do add further criteria to assess current religious conflicts.

\section{The insurmountable grip of Caste}

As Doniger ${ }^{51}$ points out, an account in Mahabharata (12.181.5-14) takes the caste question to a new level: it is the result of karma, not consanguinity. This conception of caste was reinforced through the idealization of varnāsiramadharma: obligations corresponding to one's caste and stage of life: brhmacārya (celibate student); grhastha (householder); vanaprastha (forest dweller); and samnyāsa (renouncer). Further, its

50 TAYLOR, Charles, A Secular Age, The Belknap Press of Harvard University Press, Cambridge, MA 2007, 159s.

51 Doniger, The Hindus, 286. 
social implication perpetuated the avarna (outcast) status with ambiguity, and ambivalent contemptuous/generous discard.

This process shall be seen as a desperate attempt to safeguard the caste system which perpetuates discriminatory equality of opportunity and equity in the society. However, the caste system shall be linked principally to kingship and patronage, which may not have much relevance in a more fluid and modern society. And the success of Dalits in independent India seems to point to this transformation within democracy.

The transformation of the excluded castes into a political power occurs along two lines: (1) acquisition of a consciousness of self-identity vis-à-vis Hinduism/Islam; (2) and a claim of rights within a liberal, secular, federal democracy. And the process takes diverse routes in different parts and communities of India. Hence, the overall narrative of the caste subaltern is not homogeneous, neither nationally, or culturally or religiously. Following recent studies on the topic, we shall briefly highlight two aspects (bahishkar and duhkha) of the Dalit trajectory and the ensuing issues.

In her analysis and interpretation of the Dalit subaltern, Anupama $\mathrm{Rao}^{52}$ points out that untouchability was the central issue that Ambedkar raised in criticizing caste Hinduism, in his polemics against Gandhi and in legally constituting the "Dalit vulnerability" (173). This strategy consisted in presenting untouchability as structural/inherent violence conceived, instigated and perpetuated by caste Hinduism. For "bahishkar", exclusion from society in the broad sense, "outcasting, as a sign of the structural violence of caste Hinduism ... disciplined through threats of outright violence and the quiet violence of cutting social ties" (165). Ambedkar argued that the Dalits constitute "a unique political, ethical, and historical subject" (120) whose dispossession corresponds to "the intimate violence of untouchability" (122). Exploiting this agonistic relationship with caste Hinduism, he further defined the Dalit minority status as unique, constantly under threat by the majority Hindu community, and hence requiring state protection. Dalits would not hence partake in any social justice lest they constitute an independent electorate (alike Muslims, but for different reasons) representing their own interests. For the historical and inherited non-Hindu status ("structural negativity" 134) makes them perpetually vulnerable.

52 RaO, Anupama, The Caste Question. Dalits and the Politics of Modern India, University of California Press, Berkeley, Los Angeles - London 2009. 
Despite Gandhi's objection to this demand on multiple grounds and the INC's hegemonic decision against separate electorate (137f.), Ambedkar's "articulation of the Dalit as an exceptional legal subject, marked by inherited subalternity and at risk of further violence ... [together with] Dalit recognition and (state) protection suggests that violence is a historical and cultural formation that has played a distinctive role in the formation of Dalit personhood" (167). From this perspective, ahimsā, the traditional Indic value of not doing harm to another, becomes the hermeneutical key in interpreting Dalit dispossession and in ascribing them special minority status. Both for Ambedkar and Gandhi ahimsā (understood as eradication of untouchability, and non-violence respectively) is crucial in the political realm; it enables meaningful social participation, exercise of liberal, egalitarian, democratic rights and guarantees national unity. Ambedkar's turn to Buddhism was to ensure the Dalit identity as personhood distinctively characterized by ahimsā, even at the risk of engaging in militancy to safeguard this identity.

This would take further the eventual "definition of untouchability: a list of acts, public manifestation of the practice, which encompassed ritual and symbolic humiliation as well as physical violence" (175). For, Ambedkar's decision to embrace Buddhism was based on a number of reasons, a significant one of which being his understanding of collective, social suffering as duhkha:

for him, suffering is constitutive of the very identity of the Untouchables; it is the modality in which they experience their being in the world ... [This] suffering had to be seen as socially constituted and historically specific, and could be conquered only via a creed that placed suffering at the center of its entire ethical architecture. Thus ... it was Buddhism that would best deliver the Untouchables as a group from their very specific duhkha, which was discrimination and denigration at the hands of caste Hindus ${ }^{53}$.

Besides, Buddhism as a religion has always challenged the caste system. Hence the hypothesis that the erstwhile Buddhists are the current Untouchables (234f.) turns out to be attractive to the claim of Dalit exceptionality in the political and legal spheres. However, implicit in this overarching conception of the Dalits as the caste subaltern is the conviction shared by the founders of modern India that it is "ethical sovereign-

\footnotetext{
53 VAJPEYI, Righteous Republic, 214.
} 
ty" symbolized by "the Aśokan dhammacakra and Sarnath Lion Capital" that the nation aspires (219).

One has to add to this the religious identity that Buddhism would enable the Dalits to embrace. Conversion to Buddhism denotes simultaneously "the adoption of Buddhism and the rejection of Hinduism" (221). The point is that beyond equality of citizenship and entitlement to caste-based reservation rights, Ambedkar sought religious identity to ensure Dalit self-respect independently of Hinduism, thus distinguishing from Gandhi despite conceding to the relevance of religiosity. For, "What a separate religious identity promised, eventually, was the prospect of a certain kind of authority; ... the transcendentally authoritative character of religion ...; the power to make an alternative world" (223). Buddhism, thus, guaranteed the "Untouchables to have access to a source of transcendent, world-making authority over and above the contingent and ultimately fleeting power of social movements, political parties, or state ideologies" (224). On this power of religion resides also the "quest for an authentic self" which "would have the courage to refuse ... the lowly place given to the Untouchable in the caste Hindu imagination" (225). However, Ambedkar's neo-Buddhism, Navayana, refused to endorse the classical understanding of Buddha's renunciation, parivraja, and considered him only "as a mārga-dātā (giver of a path, guide) and not a mokṣadātā (giver of transcendental emancipation, deliverer" (229). Hence the Buddhism proposed by Ambedkar amounts to: “... a religion oriented toward collective deliverance and not individual liberation; the betterment of this life and not the care of the afterlife (230).

Taking these aspects together one notices that besides ahimsā, the political relevance of religion (in this case, of Buddhism) is specified as the identity marker which both Gandhi and Ambedkar insisted upon in the constitution of modern India. This way of reinstalling religion in politics meant both a continuity with the Indic tradition (e.g. by extolling ahimsā) and a break with it (e.g. questioning the caste system). And the way Ambedkar related to the tradition was in itself challenging and innovatory; for Buddhism would have been the only conversational partner to which Hinduism listened to, in spite of the fact that in the past it successfully muted the Buddhist discourse.

If inequality indeed were the issue on which the two disagreed, as Ambedkar's incomplete outline of Indian history suggests, "by grasping that duhkha is precisely the social suffering that results from the caste system (and not the individual suffering that results from rebirth and 
karma), we can see the destruction that inequality has wreaked ..." (236). This stream of thought rightly places emphasis on social emancipation and equality, an agenda uniquely suited to the subaltern Dalit. Gandhi did not perceive this, despite his transcending of religion and adherence to an ethical politics, for his concern was more in transforming Hinduism (which though being a praiseworthy attempt, rationally and morally justifiable) than in empowering (in enlarging the capabilities of) the Dalits. The ethical sovereignty upheld in Buddhism, which Ambedkar subscribes to, defends this "overarching regime of morality, [without which] all social structures descend into a terrible condition of chaos and destitution" (241). Contemporary religious conflicts will then have to be analyzed and evaluated in reference to these markers of the independent, federal, secular democracy, briefly, the ethical sovereignty, envisioned by the founders of modern India.

This would also take us directly into the distinction between religion conflict and religious conflict mentioned at the beginning of this essay. There it has been argued that 'religion conflict' discounts religion as a no-value, whereas 'religious conflict' counts it as a human, trans-human, and social value. But in both cases it is the political relevance of religion that becomes the crucial issue: whereas for the former view religion has no place in the public sphere, the latter considers it immensely relevant in politics. One shall better capture religion conflict as "managing religion" to the advantage of the state, "public good or social stability" which has been and is the case with China ${ }^{54}$, reminding one of Emperor Claudius' strategy of religio licita applied to judge the political relevance of Christianity and the eventual expulsion of Jews (Jewish Christians) from Rome in $49 \mathrm{CE}$. Gandhi on the other hand defended the relevance of religion by calling upon the value of ahimsa enshrined in the Indic religions especially as interpreted by the $B G$, and asked Hinduism to embrace this perspective. Ambedkar also did the same but by extolling the significance of the community, in the Dalit case the import of their social suffering. In both cases religion becomes the implicit medium for the political message.

Further there is a transition in the conceptualization of socio-religious practices. The distinction in conceiving the community deserves special mention. Communalism has been held as the hallmark of Indian society since its identification under the British Raj. What Ambedkar

54 GuO, Changgang - ZHANG, Fengmei, "Religion and social stability. China's religious policies in the Age of Reform", en Third World Quarterly 36.11 (2015) 2186.2192. 
attempts amounts to a break away from this epistemological category, defining the Dalit's not by a religious creed but by their social position, hence a communitarian understanding of society. This contrast between communal and communitarian will have great implications in situating the religious conflicts, especially with respect to Hindutva and its commitment to 'secularism'. In other words, whereas Hindutva subscribes to a communal politics, the Constitution of India, alike the founders of the Indian Republic, commits to a communitarian polity, a significant difference from despising religion to acknowledging its social role as well as counting on its force to build on the national unity. 